\title{
PERAN GURU KRISTEN UNTUK MENOLONG MURID SD KORBAN PERUNDUNGAN MELALUI CERITA VIDEO ANIMASI
}

\author{
Tania Gunawan Sutaji*, Yuli Christiana Yoedo ${ }^{2}$ \\ Program Studi Pendidikan Guru Sekolah Dasar, Universitas Kristen Petra \\ Jl. Siwalankerto 121-131, Surabaya \\ E-mail: "taniagunawan96.tg@gmail.com; ${ }^{2}$ yulichy@ petra.ac.id \\ *Penulis korespondensi
}

\begin{abstract}
ABSTRAK
Perundungan merupakan suatu kondisi dimana terjadinya penyalahgunaan kekuatan maupun kekusasaan yang dilakukan seseorang maupun kelompok. Perilaku perundungan akan sangat berbahaya apabila tidak segera diatasi. Dampaknya dapat mempengaruhi gambar diri seseorang menjadi buruk. Ketika seseorang mengalami perundungan, harus segera dibantu untuk pemulihan gambar dirinya. Adapun informan yang terlibat dalam penelitian ini adalah guru Kristen yang pernah menolong murid SD korban perundungan. Peranan guru Kristen sangat diperlukan untuk menolong murid SD korban perundungan. Penelitian ini bertujuan untuk memberikan fasilitas guru Kristen untuk menolong murid SD korban perundungan melalui cerita video animasi.
\end{abstract}

Kata kunci: Dampak, gambar diri, peranan guru Kristen, perundungan, video animasi.

\begin{abstract}
Bullying is an act of abuse of strength or power by a person or group. Bullying behavior will be very dangerous if it is not stopped immediately. The impact is that it can damage a person's self-image. When a person experiences bullying, he or she should get help immediately to restore his/ her image. The informant involved in this study was a Christian teacher who had helped elementary students to break out from bullying. The role of Christian teachers is needed to help elementary school students who experiences bullying. This study aims to provide facilities for Christian teachers to help elementary school students who become victims of bullying through animated video stories.
\end{abstract}

Keywords: Animated videos, bullying, impact, self-image, the role of Christian teachers,.

\section{PENDAHULUAN}

Fenomena kekerasan dalam dunia pendidikan semakin memprihatinkan. Kekerasan simbolik dengan perundungan atau yang sering dikenal dengan istilah bullying. Malik (2014) menjelaskan bahwa peristiwa perundungan yang terjadi di ranah pendidikan diibaratkan seperti gunung es karena hanya sedikit pihak yang 
melaporkan. Komisi Perlindungan Anak Indonesia (KPAI) mencatat dalam kurun waktu 9 tahun, dari tahun 2011 sampai tahun 2019, ada 37.381 pengaduan kekerasan terhadap anak. Kasus perundungan baik di ranah pendidikan maupun sosial media, angkanya mencapai 2.473 laporan dan trennya terus meningkat. Lembaga Perlindungan Anak (LPA) menyatakan bahwa pada awal Januari 2020 hingga Maret 2020, telah terdapat 10 laporan yang masuk perihal kekerasan ataupun aksi perundungan pada anak.

Lingkungan sekolah semakin tidak aman dari perilaku kekerasan seperti perilaku perundungan. Pada tanggal 21 Februari 2020, DetikNews melansir bahwa murid kelas 1 SD dirundung oleh kakak tingkatnya di kelas 6 SD. Akibatnya, korban mengalami luka berat dan dirujuk ke RS. International Center for Research on Women (ICRW) pada tahun 2015, melaporkan sebanyak $84 \%$ anak di Indonesia mengalami kekerasan di lingkungan sekolah.

Hasil survei di atas menunjukkan bahwa kasus perundungan masih sering dialami oleh murid di lingkungan sekolah. Rosen, DeOrnelas \& Scott (2017) menjelaskan bahwa perilaku perundungan merupakan perilaku agresif dan menekan seseorang yang lebih dominan terhadap orang yang lebih lemah. Perilaku perundungan dilakukan secara terus menerus sehingga menyebabkan murid lain menderita. Melalui laporan tersebut, Riset National Association of School Psychologist menyebutkan bahwa perundungan menempati peringkat pertama yang menimbulkan ketakutan murid di sekolah.

United Nations International
Children's Emergency Fun

(UNICEF) melaporkan bahwa 50\% anak mengaku pernah mengalami perundungan di sekolah. Terdapat laporan kasus perundungan yang menyatakan bahwa $82 \%$ insiden intimidasi emosional dan 59\% insiden teman sebaya (Rosen, DeOrnelas \& Scott, 2017). Dalam laporan dinyatakan bahwa 18,9\% terjadi di lingkungan kelas dan 30,2\% terjadi ketika jam istirahat (Rosen, DeOrnelas \& Scott, 2017).

Octavia et all (2020) menjelaskan bahwa fenomena peristiwa perundungan yang terjadi di sekolah tidak disadari oleh pihak sekolah. Mengganggu teman, bertengkar, dan saling mengejek merupakan perilaku yang biasa terjadi di lingkungan sekolah (Octavia et all, 2020). Perilaku tersebut bukan hal yang bersifat mengancam sehingga perilaku perundungan tidak diketahui dan disadari oleh orangtua maupun guru.

Dewi (2020) menjelaskan bahwa perilaku perundungan terhadap murid dapat terjadi dalam 3 bentuk. Pertama, secara fisik atau paksaan, seperti memukul, menendang dan mengambil barang milik orang lain. Kedua, secara lisan atau ancaman (verbal), seperti mengejek murid, menghina, mengucapkan kata-kata yang menyinggung. Ketiga, secara psikologis seperti menggosip, mengucilkan.

Rigby (2003) menjelaskan bahwa murid sebagai korban perundungan memiliki dampak yang cukup serius. Dampak perundungan yang dialami pada masa anakanak dapat berlanjut hingga dewasa. Murid sebagai korban perundungan sering menunjukkan beberapa gejala, misalnya berpotensi cemas, depresi, kurang percaya diri, pendiam, pemalu, penakut, melamun, kehilangan konsentrasi belajar, merasa dirinya tidak berharga, merasa tidak aman, sangat hati-hati, tidak diterima di kalangan masyarakat serta dapat berpengaruh pada gambar diri seseorang. Harususilo (2020) mengatakan bahwa menurut Nadiem Makarim selaku Menteri Pendidikan dan Kebudayaan, kasus perundungan bukan permasalahan kecil yang dapat diabaikan 
dan fokus untuk melakukan pencegahan." Artinya, dampak yang dirasakan oleh korban perundungan cukup serius sehingga perlu dilakukan pencegahan dan mencari solusi sedini mungkin.

Dampak perilaku perundungan yang dirasakan oleh anak sangat berbahaya apabila tidak segera diatasi. Dampak pada sisi korban apabila tidak segera diselesaikan dengan baik, akan sangat berpengaruh pada rendahnya rasa percaya diri dan mempengaruhi buruknya gambar diri seseorang. Raja Salomo menjelaskan dalam Amsal 23:7 "for as he thinks within himself, so he is." Artinya gambar diri adalah apa yang kita pikirkan dan rasakan tentang diri kita.

Sidjabat (2011) menjelaskan bahwa gambar diri yang baik memampukan seseorang untuk memahami dan mengenal siapa dirinya. Seseorang yang gambar dirinya baik, ia dapat menghadapi berbagai macam keadaan yang dialaminya. Ciri-ciri gambar diri yang buruk adalah ia memandang dirinya lemah, merasa gagal, merasa tidak berdaya, tidak mampu melakukan sesuatu, kehilangan identitas diri dan tidak disukai orang lain sehingga hal itu berujung pada kehilangan daya tarik terhadap kehidupan.

Sitanggang \& Juantini (2019) menjelaskan bahwa murid SD yang menjadi korban perundungan, harus dibantu untuk memulihkan gambar dirinya. Sidjabat (2011) menjelaskan bahwa seseorang yang gambar dirinya buruk, apabila tidak segera ditangani akan dapat memberikan dampak, antara lain: pertama dari segi rohani. Ia tidak mudah untuk mempercayai dengan sepenuh hati, kebaikan, kasih dan pertolongan dari Tuhan, menganggap Tuhan tidak adil ketika masalah datang, dan pada akhirnya menyimpan akar kepahitan. Kedua dari segi psikologi. Seseorang merasa kuatir, takut menghadapi masa depan, merasa tidak memiliki kemampuan, tidak mampu memutuskan apa yang dilakukannya, dan tidak mampu mengontrol dirinya dalam bertindak. Ketiga, dari segi sosial. Seseorang akan memiliki perasaan malu, tidak berani tampil di depan umum, mengganggap dirinya tidak layak sehingga ia sulit untuk melakukan sosialisasi dan interaksi dengan baik.

Sidjabat (2011) menjelaskan bahwa guru Kristen memiliki peranan untuk mendidik, mengarahkan dan memulihkan kehidupan murid supaya mereka mengenal pribadi Yesus dalam kehidupan sehari-hari. Salah satu peran guru Kristen yaitu guru sebagai imam. Brummelen (2015) menjelaskan bahwa peran guru sebagai imam merupakan representatif Allah untuk menghadirkan kasih Allah, membantu menumbuhkan komunitas belajar yang penuh kasih dan peduli serta mendoakan setiap murid supaya mereka mengalami pemulihan hubungan relasi yang rusak. Selain itu, guru membantu memulihkan relasi mereka dengan Tuhan, sesama dan diri sendiri akibat peristiwa perundungan yang dialaminya.

Berdasarkan paparan yang telah dijelaskan, bahwa ada banyak kasus perundungan yang dialami oleh murid SD di lingkungan sekolah. Murid SD yang menjadi korban perundungan, sering kali mengalami dampak dari peristiwa tersebut. Murid yang menjadi korban perundungan perlu mendapatkan pertolongan secara khusus agar mereka dapat memulihkan gambar dirinya. Hal ini menggerakkan hati penulis untuk mengangkat topik kasus perundungan sebagai Tugas Akhir. Penulis menceritakan kisah seorang anak yang mengalami perundungan dari teman sebaya dan juga memerankan guru Kristen yang menolong murid SD korban perundungan melalui cerita video animasi. 
Mirnayenti et all (2015) telah melakukan penelitian terdahulu. Mirnayenti et all (2015) menjelaskan bahwa dengan layanan informasi melalui media video dapat mengurangi perilaku perundungan pada murid. Sennet (2006) menjelaskan bahwa dimensi visual seperti gambar, warna dan video lebih menarik karena lebih cepat ditangkap daripada teks. Penggunaan media video seperti Youtube, teacher tube, khan academy, vimeo, edpuzzle, goolge drive, TED (Technology Entertainment and Design) akan sangat membantu guru karena sudah siap saji dan siap ditayangkan (Haryatmoko, 2020). Media video yang penulis tampilkan memiliki durasi sekitar 10-15 menit.

Berdasarkan pemahaman di atas, penulis memilih media video animasi sebagai alat informasi dan pesan kepada guru. Di video ini akan membahas mengenai peran guru Kristen untuk menolong murid SD korban perundungan dengan memulihkan gambar dirinya. Melalui cerita video animasi, diharapkan guru dapat memahami inti cerita dari video tersebut.

\section{LANDASAN TEORI}

\subsection{Perundungan}

\subsubsection{Pengertian Perundungan}

American Psychological Association (2013) mengartikan perundungan adalah " a form of aggressive behavior in which someone intentionally and repeatedly causes another person injury or discomfort. Bullying can take the form of physical contact, words or subtler actions." Hal tersebut senada dengan Olweus (2006) menyatakan bahwa tindakan negatif adalah ketika satu maupun beberapa orang secara intens melukai perasaan seseorang atau membuat perasaan tidak nyaman. Dengan demikian perasaan tidak nyaman muncul karena terjadi kontak fisik, perkataan yang mengandung hinaan atau dengan hal lain yang menyakiti seseorang atau lebih dari satu orang. Perilaku tersebut dilakukan kepada orang yang memiliki kekuatan lebih rendah dan dilakukan oleh orang-orang yang lebih kuat maupun berkuasa. Pace, Lynm, dan Glass (2001) mendefinisikan perilaku perundungan menjadi tiga karakteristik, yaitu ketidakseimbangan kekuasaan, dapat dilakukan oleh seseorang atau sekelompok yang memiliki kekuasaan lebih dibandingkan korban, kecenderungan untuk melukai atau mengganggu, dan terjadi berulang kali.

\subsubsection{Faktor Munculnya Perundungan}

Hoover \& Milner (1998) menyebutkan faktor penyebab terjadinya perundungan yaitu faktor internal dan eksternal. Faktor internal yang menyebabkan perundungan seperti karakteristik kepribadian, kekerasan yang dialami sebagai pengalaman masa lalu, sikap keluarga yang memanjakan anak sehingga tidak membentuk kepribadian yang matang. Faktor eksternal yang menyebabkan perundungan seperti lingkungan dan budaya perbedaan etnis, resistensi terhadap tekanan kelompok, perbedaan keadaan fisik, masuk di sekolah yang baru, latar belakang sosial ekonomi, dan pengalaman masa lalu.

\subsubsection{Kategori Perundungan}

Zakiyah, Humaedi \& Santoso (2017) membagi pihak-pihak yang terlibat dalam perilaku perundungan, antara lain: pertama, pelaku perundungan. Pelaku perundungan merupakan seseorang yang melukai orang lain secara fisik maupun emosional. Kedua, korban perundungan. Korban perundungan merupakan seseorang yang sering menjadi target dari perilaku agresif, tindakan yang menyakitkan dan seseorang yang memperlihatkan sedikit pertahanan ketika terjadinya perilaku perundungan. Ketiga, pelaku-korban perundungan. Pelaku-korban perundungan merupakan pihak yang ikut 
terlibat dalam perilaku perundungan. Pelaku-korban perundungan dikarakteristikkan dengan reaktivitas, memiliki emosi yang buruk, mengalami kesulitan dalam akademis dan terjadinya penolakan dari teman sebaya. Keempat, saksi atau bystander. Saksi atau bystander adalah orang ketiga dibalik tindakan perundungan sebagai seseorang yang melihat dan mengamati. Saksi atau bystander dikategorikan sebagai pihak netral yang tidak terlibat dalam perilaku perundungan. Mereka tidak diperkenankan untuk melaporkan kepada orang lain. Tidak jarang pelaku perundungan memberikan ancaman kepada saksi apabila melaporkan aksi perundungan yang dilakukannya. Beberapa saksi memilih untuk diam dan menghindari supaya tidak menjadi sasaran korban perundungan.

\subsection{4.}

\section{Perundungan}

Bentuk-bentuk

Bentuk-Bentuk perundungan yang terjadi mulai dari lingkungan pergaulan hingga lingkungan sekolah sangat beragam, antara lain: Pertama, fisik: bentuk perilaku yang dapat terlihat oleh mata karena terjadi kontak fisik secara langsung antara pelaku perundungan dengan korban perundungan (Dewi, 2020). Contoh adalah memukul, menendang, melempar dengan barang, mencekik, meninju, mencakar, meludahi, menampar, menjambak, dan menjegal. Kedua, verbal: bentuk perilaku perundungan yang dapat ditangkap oleh pendengaran (Dewi, 2020). Perundungan verbal merupakan tindakan yang dilakukan dengan menggunakan kata-kata untuk menjatuhkan orang lain. Katakata merupakan alat yang kuat dan dapat mematahkan semangat seseorang. Ketiga, psikologi atau mental: bentuk perilaku perundungan yang paling berbahaya dibandingkan dengan bentuk perundungan lainnya (Dewi, 2020). Jenis perundungan ini sering kali diabaikan oleh beberapa orang karena bentuk perundungan ini melemahkan harga diri korban dan sulit untuk dideteksi dari luar (Yandri, 2014).

\subsubsection{Dampak Perundungan}

Perilaku perundungan dapat menimbulkan dampak. Seseorang yang menjadi korban perundungan, memiliki dampak yang cukup serius. Rigby (2003) menjabarkan beberapa dampak perundungan pada korban diantaranya, pertama menurunnya kesehatan fisik dan sulit tidur. Kedua, memiliki psychological well-being yang rendah seperti perasaan tidak bahagia, perasaan marah, sedih, tertekan, dan terancam ketika berada di komunitas tertentu. Ketiga, psychological distress, seperti cemas, depresi dan pikiran-pikiran untuk bunuh diri. Keempat, secara akademis mengalami poor result, seperti menurunnya prestasi akademis dan sulit konsentrasi.

\subsubsection{Mengatasi Perundungan}

Burden (2013) menjelaskan bahwa menghadapi perundungan merupakan salah satu pembelaan terbaik untuk melawan perilaku perundungan. Guru perlu mengenali tanda-tanda yang mengarah pada perilaku perundungan. Guru dapat melakukan intervensi apabila terjadi perilaku perundungan. Guru perlu menginformasikan kepada murid bahwa perilaku perundungan merupakan tindakan yang tidak dapat diterima. Beberapa tindakan yang perlu dipertimbangkan: Pertama, segera campur tangan. Guru perlu memisahkan murid yang terlibat perilaku perundungan. Guru jangan langsung bertanya tentang atau mendiskusikan alasan terjadinya perundungan. Kedua, mendapatkan faktanya. Berbicara dengan murid yang terlibat, baik peserta maupun pengamat, dan tanyakan apa yang terjadi. Guru meminta informasi lebih lanjut. Sebelum guru mengambil tindakan, guru 
harus mendapatkan informasi secara lengkap. Ketiga, guru memberitahu para murid bahwa guru menyadari perilaku mereka. Guru berbicara dengan murid yang terlibat secara terpisah. Guru membantu murid dan pengamat memahami apa yang terjadi dan mengapa itu terjadi sehingga dapat membantu mencegah insiden di masa depan. Keempat, guru mempertimbangkan intervensi yang tepat. Guru mengambil keputusan berdasarkan keadaan yang terjadi, tingkat keparahan yang dialami oleh murid, sejarah insiden dan murid yang terlibat dalam perilaku perundungan.

Salah satu cara untuk mengatasi perundungan dengan memulihkan gambar diri. Gambar diri atau yang sering disebut self-image. Champlin (2006) menjelaskan bahwa citra diri merupakan pemahaman seseorang mengenai diri individu atau yang dibayangkan. Gambar diri lebih bersifat global dan bersifat sebagai payung besar yang menaungi seluruh tindakan individu dalam berpikir maupun bertindak. Gambar diri sering dianalogikan sebagai kartu identitas individu kepada Tuhan.

Seseorang yang memiliki gambar diri buruk salah satunya penyebabnya adalah sering mendapatkan kritik dari orang lain, mendapatkan ejekan maupun hinaan dari orang lain. Fleet (1997) mengidentifikasi gambar diri yang positif dan negatif. Ciri-ciri gambar diri yang negatif, antara lain: merasa rendah diri, kurang memiliki dorongan dan semangat hidup, lebih suka menunda waktu, pemalu, sering menyendiri.

\subsection{Video Animasi}

\subsubsection{Pengertian Video Animasi}

Hadiwidjaja, Agung \& Cahyadi (n.d.) menjelaskan bahwa animasi berasal dari Bahasa Inggris yaitu animate yang artinya menghidupkan, memberi jiwa dan menggerakkan benda mati. Animasi juga berasal dari Bahasa Latin yaitu anima yang artinya menghidupkan maupun memberi nafas. Luhulima (n.d.) menyatakan bahwa animasi merupakan salah satu media pembelajaran berbasis komputer untuk memaksimalkan efek visual dan memberikan interaksi secara berlanjut sehingga pemahaman pembelajaran dapat meningkat. Hadiwidjaja, Agung \& Cahyadi (n.d.) menjelaskan bahwa animasi merupakan gambar yang bergerak berbentuk dari sekumpulan objek yang disusun secara beraturan dan mengikuti alur pergerakan. Gambar tersebut dapat berupa makhluk hidup, benda mati maupun tulisan.

Seiring berkembangnya zaman, media pembelajaran melalui video animasi mulai digunakan dalam proses pembelajaran (Luhulima, n.d.). Kelebihan dari media video animasi adalah gabungan unsur dari media lain seperti audio, teks, video, image, grafik dan sound (Hadiwidjaja, Agung \& Cahyadi, n.d.). Hadi (2017) menyatakan bahwa pergerakan sebuah objek maupun gambar dapat menarik perhatian murid untuk belajar sehingga dapat memberikan pemahaman yang lebih cepat serta murid termotivasi untuk belajar agar tidak jenuh.

\subsubsection{Tujuan Penggunaan Media Video}

Ronal Anderson (1987) mengemukakan tentang beberapa tujuan penggunaan media video, antara lain: pertama, tujuan kognitif. Kemampuan kognitif, dapat menyangkutpautkan kemampuan mengenal kembali dan kemampuan memberikan rangsangan berupa gerak dan sensasi. Dengan menggunakan video, dapat digunakan untuk menunjukkan contoh maupun cara bersikap atau berbuat dalam suatu penampilan. Khususnya penampilan interaksi manusia. Kedua, tujuan afektif. Video merupakan salah satu media yang baik dalam mempengaruhi sikap dan emosi.

\subsubsection{Manfaat Penggunaan Video}

Andi Prastowo (2012) mengungkapkan 
beberapa manfaat yang didapatkan melalui penggunaan video, antara lain: video memberikan pengalaman yang tak terduga kepada murid, memperlihatkan secara nyata sesuatu yang pada awalnya tidak bisa dilihat, menganalisis perubahan dalam periode waktu tertentu, memberikan pengalaman kepada murid untuk merasakan suatu keadaan tertentu dan memicu diskusi diantara murid. Hal ini sependapat dengan pendapat Haryatmoko (2020) yang menjelaskan bahwa murid akan memperoleh pengalaman, menemukan suatu gagasan maupun konsep yang mudah dipahami dan menarik perhatian apabila disampaikan dengan melalui video yang sederhana. Gambar, suara, warna dan video merupakan rumusan yang sederhana karena menjadi media yang tanpa penjelasan sudah bisa memberikan pemahaman.

\subsection{Pendidikan Kristen}

\subsubsection{Perundungan Menurut Prespektif Iman Kristen}

Konsep gambar diri yang benar telah dirusak oleh iblis karena dosa manusia, dimulai dari kisah Adam dan Hawa hingga sekarang. Sehingga manusia telah kehilangan kemuliaan Allah (Roma 3:23). Salah satu dosa yang merusak gambar diri manusia adalah penghinaan atau penindasan orang lain terhadap diri sendiri. Istilah yang sering disebut dengan "bully".

Daud merupakan salah satu tokoh di Alkitab yang pernah mengalami korban perundungan. Daud mendapatkan perundungan dari saudara-saudaranya. Bukan saja dari saudara-saudaranya saja tetapi Daud mendapatkan perundungan dari lawannya karena Daud melawan Goliat memakai alat yang sederhana yaitu batu kecil yang dilemparkan lewat sebuah umban (ketapel).

Amsal 11:12 mengatakan bahwa "siapa menghina sesamanya, tidak berakal budi, tetapi orang yang pandai berdiam diri." Orang yang melakukan perundungan tidak menggunakan akal budinya secara bijak dan sehat untuk menghargai dan menghormati sesamanya. Amsal 14:31 menekankan kembali bahwa "siapa yang menindas orang yang lemah, menghina Penciptanya, tetapi siapa yang menaruh belas kasihan kepada orang miskin, memuliakan Dia."

Berdasarkan pemahaman di atas, penulis merenungkan bahwa Firman Allah dengan jelas menentang perilaku perundungan. Seseorang yang menghina sesamanya berarti menghina Allah karena Allah yang menciptakan manusia serupa dan segambar dengannya serta hidup manusia itu berharga. Diam yang dimaksud adalah tidak membalas seseorang dengan kejahatan, melainkan mendoakan, memaafkan, mengampuni dan mengasihinya. Sama seperti tokoh Daud, ketika ia dirundung oleh saudarasaudaranya maupun pasukan dari lawannya, Daud tidak membalas melainkan membuktikan bahwa Allah bersama dengannya.

Ketika murid mengalami perundungan, murid berdoa dan menceritakan perasaannya ketika ia mengalami perundungan kepada Tuhan Yesus. Selain itu, murid perlu mengetahui bahwa Tuhan Yesus tidak pernah melakukan perundungan kepada anak-anakNya. Tuhan Yesus mengasihi setiap anak-anakNya. Tuhan Yesus menciptakan anak-anakNya serupa dengan segambarNya dan semua anak berharga bagi Allah.

\subsubsection{Peran Guru Kristen sebagai Imam}

Brummelen (2015) menjelaskan bahwa profesi guru merupakan sebuah panggilan melayani dan mempersiapkan murid untuk siap melayani Tuhan. Prijanto (2017) menjelaskan bahwa peran guru Kristen 
adalah untuk memenuhi panggilan Allah dalam hidupnya. 1 Petrus 2:9 menyatakan bahwa Tuhan sendiri yang memanggil guru sama seperti Tuhan memanggil semua orang percaya, untuk menjadi imam (imamat yang rajani). Brummelen (2015) menjelaskan bahwa peran guru sebagai imam merupakan perantara antara Tuhan dengan murid. Dalam peran ini, guru diberikan mandat untuk mendidik, mengarahkan dan membawa murid pada pertobatan dan pemulihan dalam hidup mereka. Guru sebagai imam merupakan representatif Allah untuk menghadirkan kasih Allah yang memulihkan hidup.

\subsubsection{Pemulihan Gambar Diri}

Tuhan menciptakan manusia menurut gambar dan rupa Allah (Kejadian 1:26). Kejadian 2:7 menjelaskan bahwa Allah sendiri yang menghembuskan rohNya ke dalam diri manusia sehingga manusia hidup dan memiliki karakter illahi. Tuhan menciptakan manusia dengan identitas diri yang utuh. Akibat kejatuhan manusia ke dalam dosa, terjadi kerusakan pada gambar diri manusia.

Beberapa faktor yang membentuk gambar diri seseorang berkaitan dengan peristiwa maupun pengalaman tertentu yang memiliki dampak besar secara pribadi, misalnya faktor pergaulan seseorang mendapatkan penghinaan, diolokolok, disepelekan, dan direndahkan. Sidjabat (2011) menjelaskan bahwa apabila seseorang mengalaminya berulang kali, hal tersebut mempengaruhi penerimaan seseorang.

Sidjabat (2011) menjelaskan bahwa ciri seseorang yang memiliki gambar diri yang buruk, ia memandang dirinya lemah, tidak berdaya, takut gagal, rasa malu yang berlebihan, kehilangan identitas diri, timbul perasaan tidak berharga, takut akan penolakan, tidak mampu melakukan sesuatu bahkan ia bisa kehilangan daya tarik terhadap kehidupan. Apabila seseorang menunjukkan ciri tersebut, ia harus segera menolongnya karena hal ini merupakan tipu daya iblis yang ingin menghancurkan gambar diri seseorang.

Pemulihan gambar diri yang baik terutama untuk korban perundungan yaitu memampukan mereka untuk memahami siapa dirinya sehingga ia dapat mengendalikan dirinya terhadap situasi yang dialaminya. Cara yang dapat dilakukan adalah mengarahkan pada penciptaan manusia bahwa setiap manusia diciptakan segambar dan serupa dengan Tuhan (Kejadian 1:26), semua manusia berharga dimata Tuhan (Yesaya 43:4) dan melakukan perbuatan baik terhadap orang lain disekitar (Lukas 6:38). Sebab pemulihan gambar diri dalam hidup seseorang akan terus berlangsung sampai orang tersebut benar-benar mengalami kebebasan yang sejati di dalam Tuhan. Artinya, orang tersebut telah mampu beradaptasi dan bersosialisasi secara positif dengan lingkungan tempat tinggalnya serta mereka semakin bertumbuh, berbuah menjadi serupa dengan Kristus dalam kehidupan sehari-hari.

\section{METODE PERANCANGAN Data Sekunder}

Data Sekunder diperoleh melalui studi literatur dengan cara mengkaji informasi melalui media cetak maupun media online seperti koran, buku, jurnal dan artikel yang dapat memuat informasi mengenai kasus perundungan sebagai informasi pendukung.

\section{ANALISI DATA}

\subsection{Analisis Masalah}

Analisis data menggunakan $5 \mathrm{~W}+1 \mathrm{H}$

a. What 
Perancangan cerita video animasi dengan judul Ketika Gita Terpuruk yang bertujuan untuk membantu murid SD korban perundungan bangkit dari keterpurukannya dan memulihkan gambar diri yang buruk.

b. Who

Murid SD. Murid SD akan belajar dan mengetahui apa itu perundungan, ciri perundungan dan dampak dari perundungan.

Guru SD Kristen. Guru SD membantu murid SD untuk memulihkan gambar diri yang buruk akibat perundungan, mengarahkan dan membawa murid pada pertobatan, pemulihan hidup serta menghadirkan kasih Allah dalam kehidupan murid.

c. When

Perancangan ini akan dimulai pada akhir bulan Oktober 2020 hingga awal bulan Desember 2020 oleh penulis di jurusan Pendidikan Guru Sekolah Dasar U.K. Petra.

d. Where

Video cerita animasi akan diputar saat jam pelajaran, misalnya pendidikan karakter. Video cerita animasi juga akan disebarkan online melalui Youtube.

e. Why

Animasi merupakan proses penggabungan antara unsur media audio, video, gambar dan sound yang menjadi satu kesatuan sehingga menarik minat belajar murid.

\section{f. How}

Membuat cerita video animasi dengan visual yang disukai oleh murid, menggunakan bahasa yang mudah dimengerti oleh murid, objek dan karakter yang sederhana agar dimengerti oleh murid serta menanamkan nilai-nilai kasih dan pengampunan.

\subsection{Kesimpulan Analisi Data}

Kasus perundungan sering kali terjadi dikalangan anak-anak. Dampak dari perundungan sangat berbahaya apabila tidak segera di atasi. Saat ini, telah terdapat berbagai macam metode pembelajaran, akan tetapi tidak semua metode pembelajaran dapat menarik minat murid. Oleh karena itu, dibutuhkan suatu media pendukung untuk memberikan pembelajaran yang menarik untuk murid.

\section{PERANCANGAN}

\subsection{Konsep Perancangan Video}

1. Format Program: Sebuah video untuk menolong korban murid SD yang mengalami perundungan dan kasus perundungan ini dekat dengan kehidupan sehari-sehari. Video ini dibuat dengan menarik dann berwarna. Terdapat tiga macam karakter anak yaitu karakter anak sebagai pelaku perundungan, anak yang menjadi saksi dan anak sebagai korban perundungan. Selain karakter anak, terdapat karakter guru Kristen. Guru Kristen tidak hanya berperan sebagai guru, melainkan mendoakan murid, memperhatikan korban perundungan dengan cara mengunjungi ke rumahnya dan menolong korban untuk memulihkan gambar dirinya.

\section{Judul Program: Ketika Gita Terpuruk}

3. Durasi: 12 menit

\section{Tujuan Program:}

5. Pesan yang disampaikan: Video ini memberikan informasi kepada murid SD untuk mengetahui apa itu perundungan, ciri perundungan dan dampak dari perundungan. Video ini juga memberikan informasi kepada murid korban perundungan bahwa setiap anak tercipta serupa dan segambar dengan Allah, membantu mereka untuk 
mengetahui apa yang seharusnya dilakukan. Akhirnya, video ini memberikan informasi kepada guru SD Kristen bahwa perannya sangat penting untuk menolong murid korban perundungan. Video ini juga menyampaikan nilai-nilai kebenaran Firman Tuhan, yaitu kasih dan pengampunan.

6. Target Sasaran

a. Demografis

- Usia: 7-12 tahun

- Jenis kelamin: Laki-laki dan perempuan

- Pendidikan: Sekolah Dasar kelas 1-6

- Kelas sosial: semua kalangan

b. Geografis

- Kota Jakarta (khususnya)

- Kota-kota yang ada di Indonesia (umum)

c. Psikografis: anak-anak yang menjadi korban perundungan.

d. Behavior: penyendiri, hilangnya identitas diri, merasa tidak berharga, minder, tertolak diantara kelompok pertemanan.

e. Cara mencapai target audience: menghubungi beberapa guru SD Kristen untuk dapat mengujicobakan produk tugas akhir kepada guru SD Kristen yang pernah membantu murid SD korban perundungan.

\subsection{Pra Produksi}

\subsubsection{Storyline video Ketika Gita Terpuruk"}

Scene 1: Alex, Tino dan Roni melihat Gita sedang memungut botol-botol bekas di dalam sampah.

Scene 2: Alex, Tino dan Roni mengolok-olok Gita dengan "Si miskin bau busuk."
Scene 3: Alex, Tino dan Roni menyiram Gita dengan air.

Scene 4: Sani menghampiri mereka dan menanyakan alasan Alex, Tino dan Roni memperlakukan Gita.

Scene 5: Gita pulang ke rumah dengan menangis dan tidak memberitahukan kepada ayahnya.

Scene 6: Gita berdiri di depan cermin dengan wajah menangis.

Scene 7: Ibu guru bertemu dengan Gita di sekolah dengan wajah sedih.

Scene 8: Alex, Tino dan Roni bertemu Gita di dekat tangga dan mereka mengolok-olok Gita.

Scene 9: Gita tidak masuk sekolah.

Scene 10: Gita tidak masuk sekolah.

Scene 11: Ibu guru menanyakan kepada murid alasan Gita tidak masuk sekolah.

Scene 12: Ibu guru melihat Gita sedang memungut botol-botol bekas di tong sampah.

Scene 13: Ibu guru melihat Gita menjual botol-botol bekas ke penjual botol-botol bekas.

Scene 14: Ibu guru melihat Gita pergi ke pasar membeli buah dan sayuran.

Scene 15: Ibu guru melihat Gita dan ayahnya dari balik jendela belakang rumah Gita.

Scene 16: Ibu guru mendoakan Gita.

Scene 17: Ibu guru, Alex, Tino dan Roni melihat Gita memungut botol-botol bekas di tong sampah.

Scene 18: Ibu guru, Alex, Tino dan Roni melihat Gita menjual botol-botol bekas ke penjual botol-botol bekas.

Scene 19: Ibu guru, Alex, Tino dan Roni melihat Gita pergi ke pasar membeli buah dan sayuran.

Scene 20: Ibu guru, Alex, Tino dan Roni melihat Gita dan ayahnya dari balik jendela belakang rumah Gita.

Scene 21: Ibu guru, Alex, Tino dan Roni 
mengunjungi rumah Gita.

Scene 22: Alex, Tino dan Roni meminta maaf kepada Gita. Ibu guru mengajak mereka untuk berdoa bersama

Scene 23: Ibu guru bersama dengan teman-teman lainnya membantu Gita dengan memberikan sumbangan.

Scene 24: Gita, Alex, Tino dan Roni bersahabat.

\subsubsection{Desain Karakter}

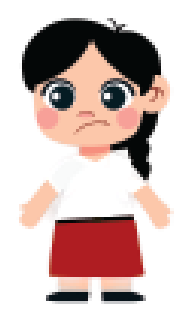

\section{Gita}

\section{Gambar 1. Tokoh Gita}

Sumber: Penulis dan Tirta, 2020

Gita merupakan tokoh utama di video ini. Ia sering mendapatkan perundungan dari Alex, Tino dan Roni.
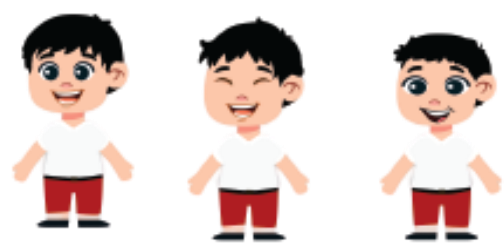

Roni

Alex

Tino

Gambar 2. Tokoh Roni, Alex dan Tino

Sumber: Penulis dan Tirta, 2020

Di video ini, Alex, Tino, Roni adalah teman Gita. Mereka memiliki karakter yang suka mengolok-olok Gita.
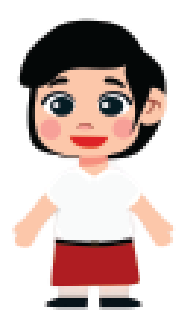

Sani

Gambar 3 Tokoh Sani

Sumber: Penulis dan Tirta, 2020

Di video ini, Sani adalah teman Gita. Sani memiliki karakter baik hati.

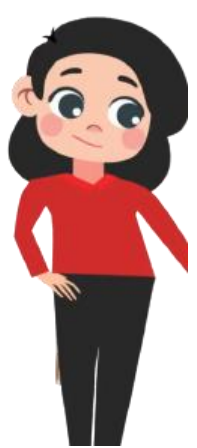

Gambar 4. Tokoh Guru

Sumber: Penulis dan Tirta, 2020

Di video ini, $\mathrm{Bu}$ Vero berperan sebagai guru SD. Bu Vero sebagai guru Kristen yang menjalankan perannya sebagai imam. $\mathrm{Bu}$ Vero mengarahkan dan membawa murid pada pertobatan, pemulihan hidup serta menghadirkan kasih Allah dalam kehidupan murid.

\subsection{Produksi}

\subsubsection{Animasi}

Animasi merupakan tahap awal dalam proses pembuatan video animasi. Animasi adalah proses untuk menggerakkan karakter, gambar maupun objek secara mekanik elektronis sehingga tampak di layar. Animasi dibuat sesuai dengan storyboard yang sudah dibuat.

\subsubsection{Background}

Setelah menyelesaikan pembuatan karakter, dan dianimasikan, tahap selanjutnya yaitu membuat latar belakang (background) supaya memperjelas cerita dan kondisi karakter. Background merupakan lokasi 
Aletheia Christian Educators Journal, Vol. 2, No. 1, April 2021, 69-83

dimana animasi berada. Penulis membuat background di sekolah, ruang kelas, jalan, pasar, kamar guru, dan rumah Gita.

\subsubsection{Dubbing}

Dubbing merupakan proses pengisian suara, merekam atau menggantikan suara untuk suatu tokoh pada karater ke dalam video animasi. Proses dubbing disesuaikan dengan dialog dan naskah cerita yang telah dibuat. Tujuannya adalah untuk menyesuaikan percakapan antar tokoh yang ada di video.

\subsection{Pasca Produksi}

\subsubsection{Editing}

Editing merupakan tahap untuk menyatukan setiap bagian yang fokusnya pada skenario cerita dan storyboard. Di tahap editing, juga menyatukan dubbing dari setiap karakter yang ada di video.

\subsubsection{Final Publikasi}

Final merupakan tahap akhir proses pembuatan video animasi. Konsep karakter, storyboard, animasi, background, dubbing, digabungkan menjadi satu kesatuan. Video animasi telah dibuat dan dipublikasikan melalui Youtube.

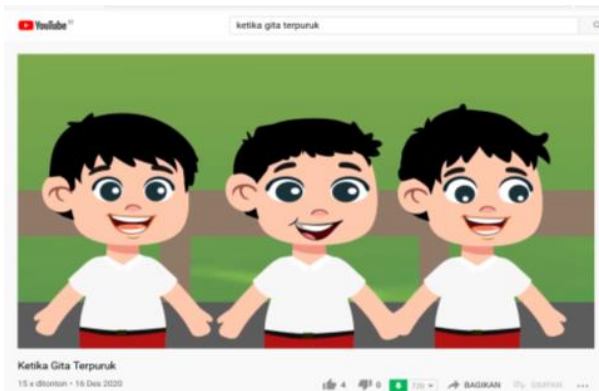

Gambar 5. Publikasi Video di Youtube

\subsection{Hasil Kerja}

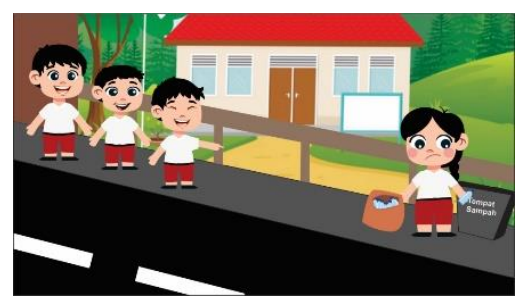

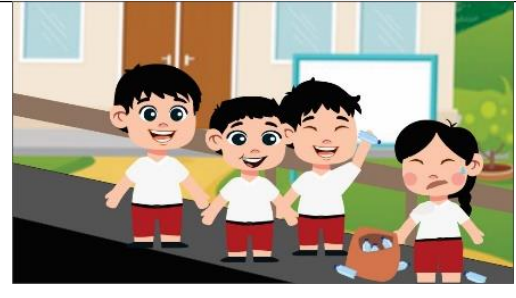
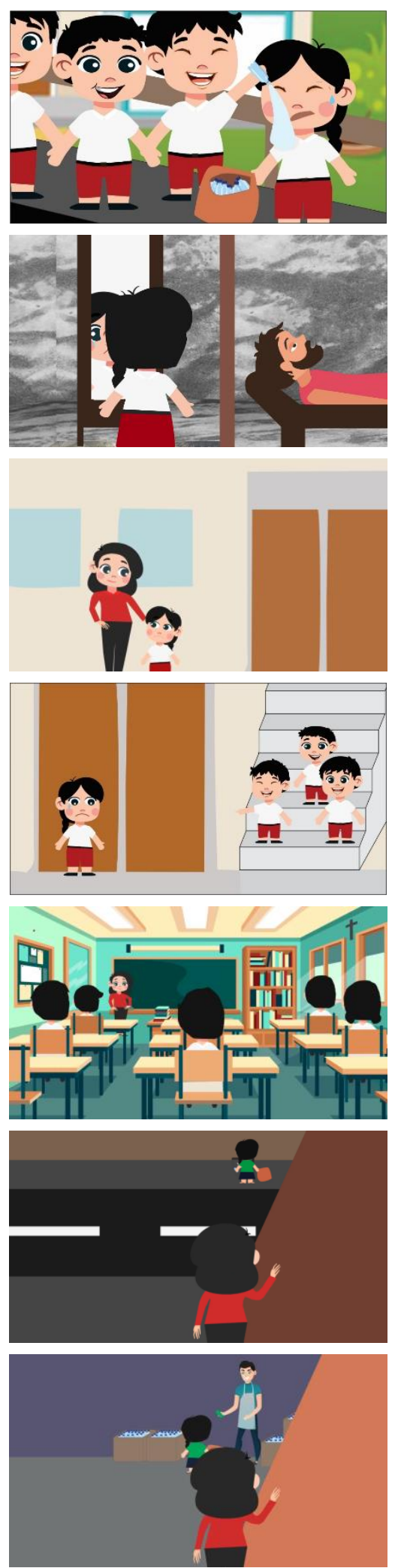

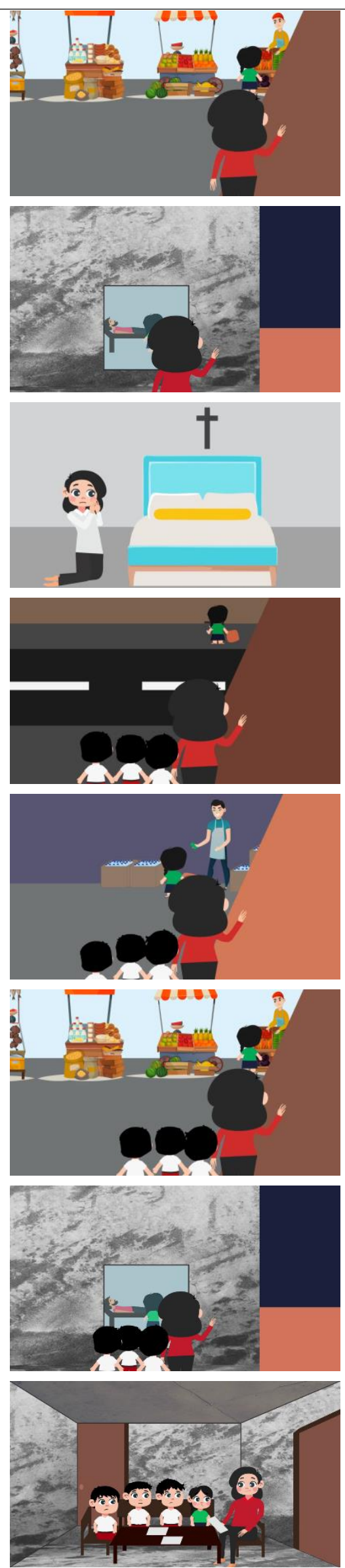
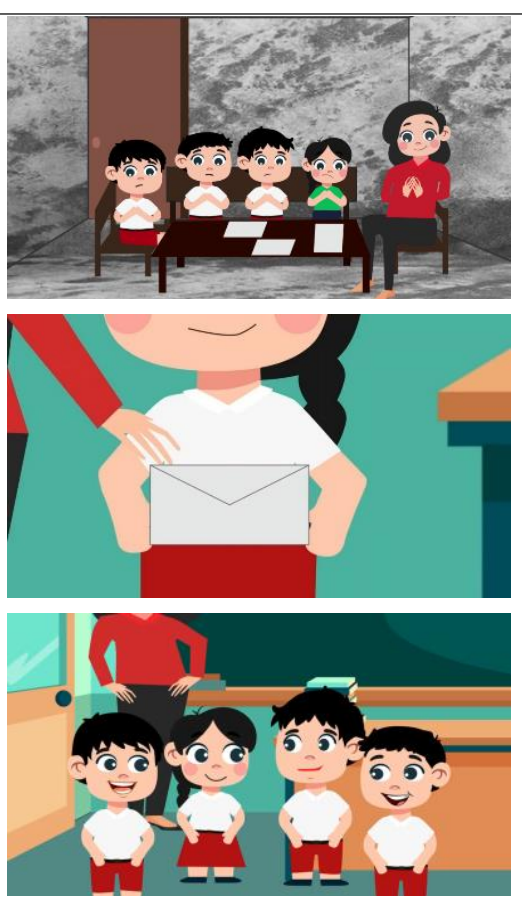

\section{KESIMPULAN}

Dalam mengerjakan perancangan video yang telah dibuat ini, perancang dapat mengambil beberapa kesimpulan, yaitu:

1. Guru menyadari bahwa peran guru Kristen tidak hanya mengajar dan memberikan ilmu pengetahuan saja, melainkan berperan aktif melindungi muridnya dari menjadi korban atau pelaku perundungan.

2. Video ini ternyata memberikan kontribusi bagi guru karena ada tindakan yang disarankan dan selama ini belum dilakukan oleh guru.

\section{DAFTAR PUSTAKA}

Andi Prastowo. 2012. Panduan Kreatif Membuat Bahan Ajar Inovatif: Menciptakan Metode Pembelajaran yang Menarik dan Menyenangkan. Yogyakarta: Diva Press.

Bonafix, Dominicus Nunnun. 2008. Animasi 3D Profesional. Jakarta: PT youtubeElex Komputindo.

Brummelen, H. V. (2015). Berjalan Bersama Tuhan di dalam Kelas (ACSI Indonesia, Trans). Surabaya: ACSI. 
Burden, P. (2013). Classroom management $\left(5^{\text {th }}\right.$ ed $)$ USA: Wiley, J. \& Sons, Inc.

Dewi, P., Y., A. (2020, March). Perilaku school bullying pada siswa sekolah dasar. Diakses dari

http://jurnal.stahnmpukuturan.ac .id/index.php/edukasi/article/vie w/526

Fleet, J., K. (1997). Menggali dan mengembangkan kekuatan tersembunyi di dalam diri. Jakarta: Mitra Utama

Hadi, S. (2017, May). Efektivitas penggunaan video sebagai media pembelajaran untuk siswa di sekolah dasar. Diakses dari

http://pasca.um.ac.id/conference s/index.php/sntepnpdas/article/v iew/849/0

Hadiwidjaja, J., X., Agung, A., \& Cahyadi, J. (2017). Peracangan video edukasi kesenian jawa karawitan dalam bentuk animasi bagi anak usia 5-6 tahun. Retrieved from http://publication.petra.ac.id/ind ex.php/dkv/article/view/5563

Harususilo, Y., E. (2020, February 29). Bullying, Nadiem: negara harus jujur dan melihat yang terjadi di sekolah. Kompas.com. Retrieved from https://edukasi.kompas.com/rea d/2020/02/29/15452511/bullyin g-nadiem-negara-harus-jujurdan-melihat-yang-terjadi-disekolah?page $=$ all

Haryatmoko. (2020). Jalan baru kepemimpinan \& pendidikan jawaban atas tantangan disrupsiinovatif. Jakarta: PT. Gramedia Pustaka Utama.

Hoover, J., \& Milner C.W. (1998). Are hazing and Bullying related to love and belongingness?
Reclaiming children and youth.

Komisi Perlindungan Anak Indonesia Online. Diakses dari https://www.kpai.go.id/berita/sejumlah -kasus-bullying-sudah-warnai-catatanmasalah-anak-di-awal-2020-beginikata-komisioner-kpai

Luhulima, D., A. (n.d). Pengembangan media video animasi untuk materi pembelajaran karakter bersaksi di sekolah minggu. Jurnal Pendidikan Agama Kristen Diakses dari https://ejournal.iaknambon.ac.id/index.php/IT/ article/view/141

Malik, Aviani. (2014, Oktober, 17). Forum Indonesia: Stop Bullying. Indonesia. Metro TV.

Mirnayenti, Syahniar \& Alizamar. (2015, June). Efektivitas layanan informasi menggunakan media animasi meningkatkan sikap anti bullying peserta didik. Diakses dari https://www.researchgate.net/publicati on/323466511_EFEKTIVITAS_LAY ANAN_INFORMASI_MENGGUNA KAN_MEDIA_ANIMASI_MENING KATKAN_SIKAP_ANTI_BULLYIN G_PESERTA_DIDIK

National Center for Education Statistic (2019). Diakses dari https://www.pacer.org/bullying/resourc es/stats.asp

Octavia, D., Puspita, M., \& Yan, L., S. (2020, June). Fenomena perilaku bullying pada anak di tingkat Sekolah Dasar. Diakses dari http://www.stikeshi.ac.id/jurnal/index.php/rik/article/vie w/273

Pace, B., Lynm, C., Glass, R., M. (2001). Bullying. Diakses dari https://www.google.com/url?sa=t\&rct= $\mathrm{j} \& \mathrm{q}=\&$ esrc $=$ s\&source $=$ web $\& \mathrm{~cd}=\& \mathrm{cad}$ $=$ rja\&uact $=8 \& v e d=2$ ahUKEwiog9PM 5ZXrAhUSfisKHW3JALAQFjAGegQ IBhAB\&url=http $\% 3 \mathrm{~A} \% 2 \mathrm{~F} \% 2 \mathrm{Fejourna}$ 1.umm.ac.id $\% 2$ Findex.php $\% 2 F j i p t \% 2 F$ article\%2FviewFile\%2F5435\%2Fpdf\& usg=AOvVaw10Vc_iztxMHR51H4IO 


\section{$\mathrm{dRhS}$}

Prijanto, J., H. (2017). Panggilan guru kristen sebagai wujud amanat agung yesus kristus dalam penanaman nilai alkitabiah pada era digital. Diakses dari https://ojs.uph.edu/index.php/PJ I/article/view/325

Rigby, K. (2003, October). Consequences of bullying in schools. Diakses dari https://pubmed.ncbi.nlm.nih.gov /14631878/

Rosen, L., H., DeOrnelas, K., \& Scott, S., R. (2017). Bullying in School. Texas: USA

Sidjabat, B., S. (2011). Membangun Pribadi Unggul. Yogyakarta: Andi.

Sitanggang, M., H. \& Juantini. (2019, Januari). Citra diri menurut Kejadian 1:26 dan aplikasinya bagi pengurus pemuda remaja gpdi hebronmalang. Diakses dari https://journal.sttsimpson.ac.id/i ndex.php/EJTI/article/view/118/ pdf

Yandri, H. (2014, Desember). Peran guru bk/konselor dalam pencegahan tindakan bullying di sekolah. Diakses dari http://ejournal.stkip-pgrisumbar.ac.id/index.php/pelangi/ article/view/155

Zakiyah, E., Z., Humaedi, S., \& Santoso, M., B. (2017, July). Faktor yang mempengaruhi remaja dalam melakukan bullying. Diakses dari http://jurnal.unpad.ac.id/prosidi ng/article/view/14352 